Meta

Journal des traducteurs

Translators' Journal

\title{
Translation Studies - Interdisciplinary, Multidisciplinary or Transdisciplinary?
}

\section{Martina Ožbot}

Volume 60, numéro 2, août 2015

$60^{\mathrm{e}}$ anniversaire. Les horizons de la traduction : retour vers le futur $60^{\text {th }}$ Anniversary. Translation's Horizons: Back to the Future

60mo aniversario. Los horizontes de la traducción: regreso al futuro

URI : https://id.erudit.org/iderudit/1032911ar

DOI : https://doi.org/10.7202/1032911ar

Aller au sommaire du numéro

Éditeur(s)

Les Presses de l’Université de Montréal

ISSN

0026-0452 (imprimé)

1492-1421 (numérique)

Découvrir la revue

Citer ce document

Ožbot, M. (2015). Translation Studies - Interdisciplinary, Multidisciplinary or Transdisciplinary? Meta, 60(2), 360-360. https://doi.org/10.7202/1032911ar d'utilisation que vous pouvez consulter en ligne. 


\title{
Translation Studies - Interdisciplinary, Multidisciplinary or Transdisciplinary?
}

\author{
Martina Ožbot \\ University of Ljubljana, Ljubljana, Slovenia \\ martina.ozbot@guest.arnes.si
}

The aim of the paper is to discuss the concept of interdisciplinarity as a fundamental paradigm of modern research, presenting some of its characteristics as well as some problems arising in connection with it. The notion of interdisciplinarity (as well as those of multidisciplinarity and transdisciplinarity) will be examined in the context of the development of Translation Studies as an autonomous discipline, which formed out of linguistics, literary studies and some other fields, and which is today considered of eminently interdisciplinary nature. The fundamental question to be addressed is the relationship between the new interdiscipline and the disciplines from which it has derived, and its autonomy with regard to those disciplines. Taking into account practical as well as epistemological circumstances which favoured the rise of Translation Studies, the presentation will go on to explore in particular the nature of the relationship between the study of language and the study of translation, emphasizing the ambivalent role played by linguistics (and philology) in the advancement of the new research field, on the one hand hindering its development and marginalizing its relevance, while on the other hand actually making it possible as a result of some fresh discourse-oriented approaches to the study of language and of new insights into its functioning in texts, which gradually became available from the 1960's on. It will be suggested that to a significant degree the study of language and the study of translation continue to be inextricably linked - so much so that the customary disciplinary divisions appear to be relatively arbitrary and motivated by pragmatic reasons rather than justified by the inherent nature of the research object.

Martina Ožbot is a professor of Italian at the Faculty of Arts of the University of Ljubljana (Slovenia). Her primary research fields are translation history and translation theory. She has authored a number of publications, among which there are also two monographs: Textual coherence and translation strategies in the Slovene translations of Machiavelli's Prince (2006) and Translation Stories: Studies in translation history and theory, with a focus on Slovene-Italian relations (2012). She is editor-in-chief of Hieronymus, a translation journal published by the Slovene Association of Literary Translators and editor of the academic book series "Studia Translatoria." When time allows, she is also a practising translator; among other things, she produced a Slovene version of Edward Sapir's classic Language. 